\title{
Disposition of Radiolabelled Insulin-Like Growth Factor I (IGF-I), IGF-II and Their N-Terminal Truncated Variants in Rats
}

\author{
HIROYUKI YAMAMOTO, LIAM J. MURPHY*, AND YUZURU KATO \\ First Division, Department of Medicine, Shimane Medical University, Izumo 693, Japan and \\ *Departments of Internal Medicine and Physiology, University of Manitoba, Winnipeg, MB R3E OW3, Canada
}

THE MAJORITY of circulating insulin-like growth factors I (IGF-Is) and IGF-IIs are bound to a family of high affinity binding proteins, IGF binding proteins (IGFBPs). These IGFBPs are considered to modify the bioavailability of IGFs, and can inhibit and enhance IGF-I action under various conditions in vitro [1]. The complex of IGF-IGFBPs has a relatively long half-life and is present in the intravascular space $[2,3]$. N-terminal truncated variants of IGF-I and IGF-II, des (1-3) IGF-I $[4,5]$ and des (1-6) IGF-II [6], are biologically more potent than intact IGF-I and IGF-II, respectively, because these variants have reduced affinity for the IGFBPs but their affinity for the type-I IGF receptor is similar to that of intact IGF. Des (1-3) IGF-I has been identified in a variety of tissue extracts and biological fluids [7-10], whereas des (1-6) IGF-II has not yet been found. Our recent demonstration of a protease in the rat serum which is capable of generating des (1-3) IGF-I from IGF-I [11] suggests that N-terminal truncation of IGFs regulates the bioavailability of these growth factors. In the present study, we compared the serum half-life, tissue uptake and urinary excretion of these truncated IGF variants with those of their intact precursors.

\section{Materials and Methods}

125I-labelled IGF-I, des (1-3) IGF-I, IGF-II and des

Correspondence to: Dr. Hiroyuki YAMAMOTO, First Division, Department of Medicine, Shimane Medical University, 89-1 Enya-cho, Izumo 693, Japan

Key words: Half-life, Tissue uptake, Insulin-like growth factor-I (IGF-I), IGF-II, N-terminal truncated IGFs
(1-6) IGF-II $\left(2 \times 10^{6} \mathrm{cpm}\right.$ each $)$ was bolusly injected into the left jugular vein of male Sprague-Dawley rats (BW 250-300 g) under ketamine anesthesia. $200 \mu l$ blood samples were obtained from the right femoral artery at 1, 3, 5, $10,15,30,60,120,180$ and $240 \mathrm{~min}$ after the injection. Urine samples were collected at $30 \mathrm{~min}$ intervals via the implanted bladder catheter. Tissues were prepared on ice immediately after exsanguination by decapitation at $2 \mathrm{~h}$ after the injection. The radioactivity of these samples was measured with a gamma counter.

\section{Results}

The serum disappearance curves of the radiolabeled peptides are shown in Fig. 1. Mean $( \pm$ SEM) values of the half-life of des (1-3) IGF-I, IGF-I, des (1-6) IGF-II and IGF-II were $20.5 \pm 4.0,228.3 \pm$ $22.0,21.3 \pm 1.1$ and $181.7 \pm 13.3 \mathrm{~min}$, respectively.

The tissue uptake of the radiolabeled peptides is shown in Fig. 2A. Maximal accumulation of all 4 radiolabeled peptides was found in the kidneys. The tissue uptake for ${ }^{125}$ I-IGF-I was distributed in the following order: the kidneys $>$ pancreas $>$ small intestine $>$ liver $>$ duodenum $>$ stomach $>$ the lungs $>$ spleen $>$ heart $>$ large intestine $>$ testes $>$ brain $>$ skeletal muscle. A similar pattern was found with 125I-IGF-II. The tissue uptake ratio of truncated IGFs to intact IGFs is shown in Fig. 2B. Skeletal muscle, kidneys and testes showed a preferential uptake of both truncated variants. Intestines, duodenum and stomach showed preferential uptake of des (1-6) IGF-II. Both the pancreas and brain favoured uptake of intact IGF-I compared to des (1-3) IGF-I. The ratio of des (1-6) IGF-II to 


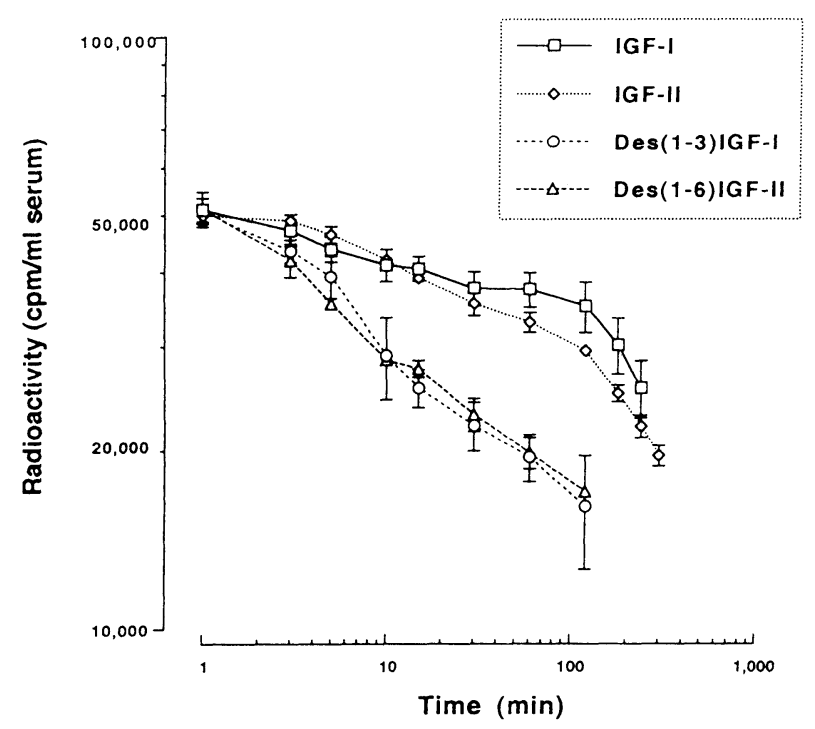

Fig. 1. Disappearance of ${ }^{125}$ I-labeled IGF-I, des (1-3) IGF-I, IGF-II or des (1-6) IGF-II from the circulation in the rat. Residual radioactivities in serum were measured after a bolus i.v. injection of either radiolabelled peptide $\left(2 \times 10^{6} \mathrm{cpm}\right)$. Mean \pm SEM values for three rats are shown.

intact IGF-II was lower in the spleen, liver and brain.

The accumulated radioactivity in the urine was measured at $30 \mathrm{~min}$ interval. Urinary excretions of radiolabelled truncated IGF-I and IGF-II for 120 min were much greater than those of intact IGF-I and IGF-II, respectively (\% excretion of injected peptide: 3.0 vs. $1.3 \%, 5.0$ vs. $0.7 \%$ ).

\section{Discussion}

The recent identification and characterization of an acid protease capable of generating $\mathrm{N}$-terminal truncated IGF-I have renewed interest in the physiological relevance of this variant [11]. The presence of des (1-3) IGF-I in a variety of tissues and biological fluids [7-10], the demonstration of enhanced biological activity of this variant in both in vitro and in vivo assays $[4,5]$ and the observation suggesting that the proteolytic activity which generates this IGF-I variant is inversely regulated by growth hormone [12] suggest that the generation of des (1-3) IGF-I is unlikely to represent an unimportant degradation pathway. Furthermore, although des (1-3) IGF-I has not been detected in

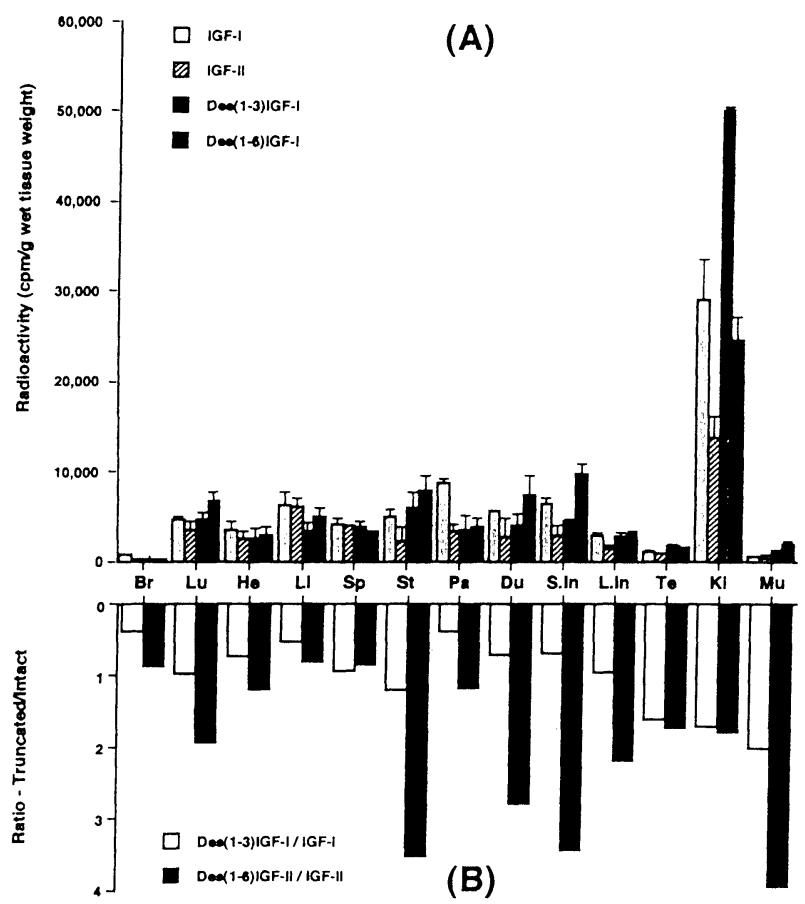

Fig. 2. A) Accumulated radioactivity in rat tissues at $2 \mathrm{~h}$ after a bolus injection of radiolabeled peptides (upper pannel). B) The tissue uptake ratio of truncated IGF to intact IGF (lower pannel). The abbreviations are: $\mathrm{Br}$, brain; $\mathrm{Lu}$, lung; $\mathrm{He}$, heart; $\mathrm{Li}$, liver; $\mathrm{Sp}$, spleen; $\mathrm{St}$, stomach; $\mathrm{Pa}$, pancreas; $\mathrm{Du}$, duodenum; S.In, small intestine; L.In, large intestine; Te, testis; $\mathrm{Ki}$, kidney; Mu, skeletal muscle.

plasma, it is unlikely to be an artifact resulting from tissue disruption during extraction since it is also present in breast milk and possibly in urine $[10,13]$. The earlier failure to demonstrate truncated variants in IGF preparations derived from plasma may be explained by the fact that the truncated variants of IGF-I and -II are rapidly cleared from plasma. The serum half-life of radiolabeled IGF-I, determined in the present study by means of a relatively simple protocol, is in close agreement with that reported in the literature. Ballard et al. [14] reported that a clearance rate for des (13) IGF-I was approximately 5 fold greater than IGF-I. The half-life of ${ }^{125}$ I-des (1-6) IGF-II had not been previously determined. We found that the $t_{1 / 2}$ for radiolabeled IGF-II was similar to that of IGF-I, which is comparable with the previous report that the clearance rate for IGF-II is similar to that for IGF-I in adult rats: $1.34 \pm 0.17$ vs. $1.11 \pm$ $0.13 \mathrm{ml} / \mathrm{min}$ per $\mathrm{kg}$ [14]. 
The kidney is the major organ for clearance of the IGFs and their variants from the circulation. Of the tissues examined, the brain, the pancreas and the liver showed more uptake of IGF-I than des (1-3) IGF-I. These data suggest that the IGFBPs are important for specifically facilitating tissue uptake in these tissue. In contrast, skeletal muscle and testes showed uptake des (1-3) IGF-I greater than IGF-I, indicating that the ability to bind to the IGFBPs inhibits uptake in these tissues. This tissue specificity may result in the relative abundance of the different IGFBPs expressed in the tissue or capillaries, or in the interaction of circulating IGFBPs with tissue capillary endothelium [15]. Differences in the tissue uptake and the subendothelial localization of IGF-I coupled with various IGFBPs have been demonstrated [16]. Tissue uptake would also be dependent upon the abundance of the IGF receptors. More marked differences were apparent when tissue uptake of des (1-6) IGFII and IGF-II were compared. Since des (1-6) IGF-II has reduced affinity for the IGF type 2 receptor compared to IGF-II, as well as reduced affinity for the IGFBPs, the relative proportions of type 1 and type 2 receptors in different tissues may also be important in determining the tissue uptake and action of des (1-6) IGF-II.

The present findings demonstrate that the truncated variants of IGF-I and IGF-II are rapidly cleared from circulation in the rat primarily through the kidneys. The physiological significance of preferential uptake of the truncated variants by some tissues and the different uptake pattern for des (1-3) IGF-I and des (1-6) IGF-II remains to be further investigated.

\section{References}

1. Rechler MM (1993) Insulin-like growth factor binding proteins. Vitamins Horm 47: 1-114.

2. Guler H-P, Zapf J, Schmid C, Froesch ER (1989) Insulin-like growth factor I and II in healthy man. Estimations of half-lives and production rates. Acta Endocrinol 121: 753-758.

3. Baxter RC, Martin JL (1989) Structure of the Mr 140,000 growth hormone-dependent insulin-like growth factor binding protein complex: Determination by reconstitution and affinity labeling. Proc Natl Acad Sci USA 86: 6898-6902.

4. Gillespie C, Read LC, Bagley CJ, Ballard FJ (1990) Enhanced potency of truncated insulin-like growth factor-I (des (1-3) IGF-I) relative to IGF-I in lit/lit mice. J Endocrinol 127: 401-405.

5. Tomas FM, Knowles SE, Owens PC, Read LC, Chandler CS, Gargosky SE, Ballard FJ (1991) Effects of full-length and truncated insulin-like growth factor-I on nitrogen balance and muscle protein metabolism in nitrogen-restricted rats. J Endocrinol 128: 97-105.

6. Luthi C, Roth BV, Humbel RE (1992) Mutants of human insulin-like growth factor II (IGF-II), expression and characterization of truncated IGF-II and of two naturally occurring variants. Eur J Biochem 205: 483-490.

7. Carlsson-Skwirut C, Jørnvall H, Holmgren A, Anderson C, Bergman T, Lundquist G, Sjøgren B, Sara VR (1986) Isolation and characterization of variant IGF-1 as well as IGF-2 from adult human brain. FEBS Letters 201: 46-50.

8. Sara VR, Carlsson-Skwirut C, Andersson C, Hall K,
Sjøgren B, Holmgren A, Jørnvall H (1986) Characterization of somatomedins from human fetal brain: Identification of a variant form of insulin-like growth factor-I. Proc Natl Acad Sci USA 83: 49044907.

9. Ogasawara M, Karey KP, Marquardt H, Sirbasku DA (1989) Identification and purification of truncated insulin-like growth factor I from porcine uterus. Evidence for high biological potency. Biochemistry 28: 2710-2721.

10. Francis GL, Read LC, Ballard FJ, Bagley CJ, Upton FM, Gravestock PM, Wallace JC (1986) Purification and partial sequence analysis of insulin-like growth factor-I from bovine colostrum. Biochem J 233: 207213.

11. Yamamoto H, Murphy LJ (1994) Generation of des (1-3) insulin-like growth factor-I in serum by an acid protease. Endocrinology 135: 2432-2440.

12. Yamamoto H, Murphy LJ (1995) Enzymatic conversion of insulin-like growth factor I (IGF-I) to des (1-3) IGF-I in rat serum and tissue: A further site of growth hormone regulation of IGF-I action. $J$ Endocrinol 146: 141-148.

13. Yamamoto H, Murphy LJ (1995) N-terminal truncated insulin-like growth factor-I in human urine. $J$ Clin Endocrinol Metab 80: 1179-1184.

14. Ballard FJ, Knowles SE, Walton PE, Edson K, Owens PC, Mohler MA, Ferraiolo BL (1991) Plasma clearance and tissue distribution of labelled insulin-like growth factor-I (IGF-I), IGF-II and des (1-3) IGF-I in rats. J Endocrinol 128: 197-204.

15. Boes M, Booth BA, Sandra A, Dake BL, Bergold A, 
Bar RS (1992) Insulin-like binding protein (IGFBP) 4 accounts for the connective tissue distribution of endothelial cell IGFBPs perfused through the isolated heart. Endocrinology 131: 327-330.
16. Moser DR, Lowe Jr WL, Dake BL, Booth BA, Boes M, Clemmons DR, Bar RS (1992) Endothelial cells express insulin-like growth factor-binding proteins 2 to 6. Mol Endocrinol 6: 1805-1814. 